\title{
Bad Homburg Conference on Social Protest, Violence and Terror
}

\section{Andrew R. Carlson}

An academic conference of significance to anyone interested in international labor and working class history was held at Bad Homburg, Germany, November 15-17, 1979. The theme of the three day affair, "Sozialprotest, Gewalt, Terror, Gewaltanwendung durch politische und gesellschaftliche Randgruppen im 19. und 20. Jahrhundert." (Social protest, violence and terror resorted to by social and political fringe groups in the 19th and 20th centuries) was the inspiration of the seminal mind of Prof. Dr. Wolfgang J. Mommsen, Director of the Deutsches Historisches Institut London, which sponsored the Conference in conjunction with the Werner Reimers Stiftung.

The conference sought to arrive at a comparative analysis of both the older forms of social protest, which often seemed legitimate, and the more modern forms of aggressive terrorist activities such as anarchism. The scope of the conference was limited to Europe and the British Isles in the 19th and 20th centuries. Several participants expressed regret at not including third world countries, but everyone realized that to have included them would have rendered the conference unwieldy.

The real significance of the conference lies in the attempt to look at the recent revival of extremist movements in Europe in an historical perspective, which has been lacking in psychological and sociological analyses of these phenomena. The papers and discussion struck down the erroneous assumption that what is being dealt with in these recent extremist movements is a completely new phenomenon, for which there are hardly any precedents in the past. The Irish example provided the best example of historical continuity from the 19th century through to the present-day activities in Northern Ireland.

It would be impossible to summarize the proceedings of the three days of papers and discussion. The papers presented, along with the part of the discussion that was taped, will be published by Klett-Cotta, Stuttgart in German. An English version is also planned. In general the papers were excellent, and some were outstanding. A listing of the papers presented and participants should be useful for someone wishing to pursue a topic of special interest to them. Further information on a particular paper may be obtained by writing directly to the individual who 
presented it, or to the German Historical Institute London, 42 Russell Square, London WC1B 5DA.

The sessions were as follows:

I Sozialprotest und Gewalt im 18. und 19. Jahrhundert. Chairman, Prof. Dr. Wolfgang J. Mommsen, German Historical Institute London.

(1.) Prof. Franklin L. Ford, Harvard University, "Reflections on Political Violence: Europe in the Nineteenth and Twentieth Centuries."

(2.) Prof. Eric Hobsbawn, Birbeck College, London, Commentator, "Violence and Social Protest in the 19th Century.",

(3.) Prof. Malcolm I. Thomas, University of Queensland, Australia, "The Aims and Ideology of Violent Protest in Great Britain 1800-1848.",

(4.) Prof. Dr. Heinrich Volkmann, Freie Universität Berlin, "Form Träger und Mittel des socialen Protestes im deutschen Vormärz."

(5.) Dr. Hans-Gerhard Husung, German Historical Institute London, "Kollektiver Gewaltprotest im norddeutschen Vormärz.",

II Gewalt und Terror im zaristischen Russland, Chairman Prof. Dr. Peter Scheibert, Universität Marburg.

(1.) Dr. Astrid Von Borcke, Bundesinstitut für ostwissensch. Studien, Köln, "Terror und Gewalt im narodničestvo: Die 'Partei' Narodnaja volja.",

(2.) Mrs. Maureen Perrie, University of Birmingham, "Political and Economic Terror in the Tactics of the Russian SocialistRevolutionary Party before 1914."

(3.) Dr. Manfred Hildermeier, Freie Universität Berlin, Commentary on Mrs. Perrie's paper.

III Spain, Chairman, Prof. Eric Hobsbawn, Birbeck College, London.

(1.) Prof. Raymond Carr, St. Anthony's College, Oxford, "Labor Violence in Vizcaya and Catalonia: A Comparison."

(2.) Dr. Walter Bernecker, Universität Augsburg, "Strategien der 'direkten Aktion' und der Gewaltanwendung im spanischen Anarchismus."

(3.) Dr. Gerhard Brunn, Universität Köln, "Gewalt und Terror in den spanischen Nationalbewegungen.",

IV Dr. Arthur Lehning, Universität Amsterdam, "Das Problem der Gewaltanwendung bei Bakunin und Netschajew."

V Ireland, Chairman, Prof. Kevin B. Nowland, University College, Dublin.

(1.) Dr. Peter Alter, Deutsche Historische Institute London, “Traditionen der Gewaltanwendung in der irischen Nationalbewegung des 19. Jahrhunderts." 
(2.) Dr. Michael Laffan, University College, Dublin, "Violence and Terror in Twentieth Century Ireland: the IRB and the IRA."

VI Strategien der Gewalt und des Anarchismus im deutschen Kaiserreich, Chairman, Prof. Dr. H.-J. Steinberg, Universität Bremen.

(1.) Dr. Andrew R. Carlson, 968 124th Avenue, Shelbyville, Michigan 49344, U.S.A., "Anarchism and Individual Terror in the German Empire 1870-1890."

(2.) Dr. Ulrich Linse, Pentbergerstr. 13, D-8000, München 70, Germany, “' Propaganda der Tat' und 'Direkte Aktion' im deutschen Anarchismus und Anarcho-Syndikalismus."

(3.) Dr. Gerhard Botz, Universität Linz, "Gewaltstrategien und ihre anwendung in der 1. österreichischen Republik."

VII Syndikalismus, der ital. Faschismus, Chairman, Prof. Roberto Vivarelli, University of Florence, Italy.

(1.) Prof. F.F. Ridley, University of Liverpool, "Revolutionary Syndicalism in France: The Strike as Direct Action."

(2.) Prof. Dr. Wilfried Röhrich, Kiel, "Der Mythos der Gewalt. Sorel: Vom Syndikalismus zum Faschismus."

(3.) Prof. Adrian Lyttleton, John Hopkins Centre, Bologna, "Fascism and Violence in Post-War Italy: Strategy and Social Conflict."' Conflict."

(4.) Dr. Jens Petersen, Deutsche Historische Institut, Rome, "Das Problem der Gewalt im italienischen Faschismus 1919-1925."

VIII Terror und Gewalt in der Weimarer Republik, Chairman, Prof. Francis L. Carsten, School of Slavonic and East European Studies, London.

(1.) Dr. David B. Soutnern, Darwin College, University of Kent, "Anti-Democratic Terror in the Weimar Republic: the Fememorder and the Schwarze Reichwehr."

(2.) Miss Eve Rosenhaft, King's College, Cambridge, "The KPD and the Problem of Terror in the Third Phase of the Weimar Republic."

(3.) Prof. Peter Merkl, University of California, Santa Barbara, "Approaches to Political Violence: the Stormtroopers of 1925-1933."

IX Final Discussion, Chairman, Prof. Eric Hobsbawm, Birbeck College, London.

A number of people were invited to the conference to participate in the discussion. They were: Prof. Roderick Aya, Universität Amsterdam; Prof. Dr. A. Block, Soest/Niederlande; Miss Bettina Dürr, Düsseldorf; Mr. Gerhard Hirschfeld, Deutsches Historisches Institut London; Mr. Alf Lüdtke, Max-PlanckInstitut für Geschichte, Göttingen; Prof. Richard Tilly, Universität Münster, who added much to the discussion with his comparative analysis; Dr. Joachim Wagner, 
NDR, Hamburg; Prof. Gwyn A. Williams, University College Cardiff, Wales, who made a substantial contribution by bringing in the situation in Wales.

The participants at the conference agreed that the papers and discussion were worthwhile and that a good beginning had been made toward looking at terrorism from an historical perspective. 